\title{
THE EFFECT OF ORGANIC CO-CONTAMINANTS ON TECHNETIUM AND RHENIUM SPECIATION AND SOLUBILITY UNDER REDUCING CONDITIONS
}

\author{
Estela Reinoso Maset ${ }^{1,2}$, Stephanie Handley ${ }^{1}$, Andrew Fisher ${ }^{1}$, Andrew Heydon ${ }^{1}$, \\ Paul J. Worsfold ${ }^{1}$, Andrew J. Cartwright ${ }^{1}$, and Miranda J. Keith-Roach ${ }^{* 1}$
}
${ }^{1}$ School of Earth, Ocean and Environmental Sciences, University of Plymouth, Drake Circus, Plymouth PL4 8AA, UK.
${ }^{2}$ Departamento de Química Analítica e Alimentaria, Universidade de Vigo, Lagoas Marcosende s/n, 36200 Vigo, Spain 랄eith-roach@plymouth.ac.uk; tel: +44 1752233048

Journal: Environmental Science and Technology

Date document prepared: $15^{\text {th }}$ May 2006

Number of pages: 3

Number of tables: 2 
Table S1: Bulk soil XRF results, the concentration of each compound is quoted as $\%$ of total soil mass.

\begin{tabular}{ccccccc}
\hline $\mathrm{SiO}_{2}$ & $\mathrm{TiO}_{2}$ & $\mathrm{Al}_{2} \mathrm{O}_{3}$ & $\mathrm{Fe}_{2} \mathbf{O}_{3}$ & $\mathrm{MnO}$ & $\mathrm{MgO}$ & $\mathrm{CaO}$ \\
\hline 57.18 & 1.08 & 13.73 & 5.97 & 0.19 & 0.34 & 0.38 \\
$\mathrm{Na}_{2} \mathrm{O}$ & $\mathrm{K}_{2} \mathrm{O}$ & $\mathbf{P}_{2} \mathbf{O}_{5}$ & $\mathrm{SO}_{3}$ & $\mathrm{H}_{2} \mathbf{O}$ & $\mathbf{C O}_{2}$ & Total \\
\hline 0.40 & 1.76 & 2.61 & 0.26 & 4.45 & 11.63 & 99.98 \\
\hline
\end{tabular}


Table S2. Reproducibility of the HPLC-ICP-MS analysis for triplicate samples of $\mathrm{ReO}_{4}{ }^{-}(0.27 \mu \mathrm{M})$ and $\mathrm{TcO}_{4}{ }^{-}(0.50 \mu \mathrm{M})$, and for Tc(IV)-EDTA following reduction of $\mathrm{TcO}_{4}{ }^{-}(0.50 \mu \mathrm{M})$ by $1 \mathrm{mM} \mathrm{Sn}(\mathrm{II})$. The $\% \mathrm{RSD}$ is $1 \sigma(\mathrm{n}=3)$.

\begin{tabular}{ccc}
\hline Species & Average peak integral & \%RSD \\
\hline $\mathrm{ReO}_{4}{ }^{-}$ & 22940 & 1.0 \\
$\mathrm{TcO}_{4}^{-}$ & 37560 & 2.9 \\
Tc-EDTA & 36360 & 2.8 \\
\hline
\end{tabular}

